\title{
Factors Affecting Root Rot Control in Mulched Avocado Orchards
}

Jim Downer, ${ }^{1}$ Ben Faber, ${ }^{2}$ and John Menge ${ }^{3}$

Additional IndeX words. Ashburner system, biological control, cellulase, microbial activity, Persea americana, Phytophthora cinnamomi

Summary. Mulches can exert positive (disease controlling) or negative (disease enhancing) potential when applied to young avocado (Persea americana) trees. Regulation of root disease in avocado is a complicated process that is affected by host resistance, inoculum density, temperature, soil salinity and soil water potential. There are short-term immediate effects from mulching and subtle long-term effects that regulate disease caused by the root rot pathogen Phytophthora cinnamomi. Short-term effects include increased soil moisture and soil temperature moderation. Long-term effects include increases of: soil mineral nutrients, soil aggregation and drainage; microbial activity; and cellulase enzyme activities. Biological control of Phytophthora in mulched soil is partially regulated by cellulase enzyme activities. This soil enzyme concept of biological control is discussed in regard to the classical Ashburner method of biological control.

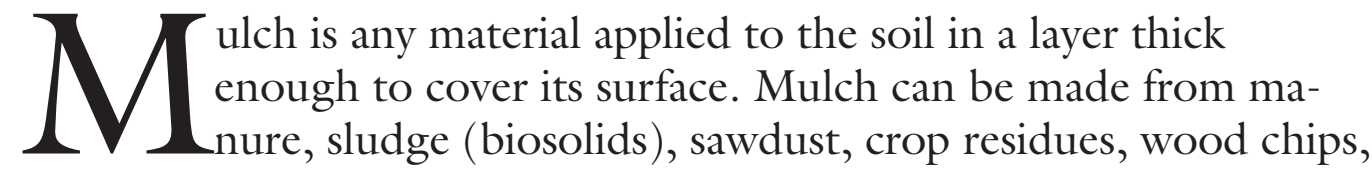
straw, shredded prunings, plant foliage, paper, plastic or other polymers, sand, gravel or rock. Although most of these materials can influence growth of crops, variability of organic substrates makes it difficult to draw unifying conclusions on how to use mulch to control plant diseases. Since the effects of individual mulch types on specific diseases and crop systems are likely unique, a decision to use mulch for disease control should be supported with research on what a specific mulch will do in a specific disease situation.

In this paper we will specifically discuss root disease of avocado caused by Phytophthora cinnamomi, conditions favoring disease in organic systems and other mulch effects that may regulate disease.

\section{Soil mineral nutrition}

Organic mulches can significantly increase soil mineral nutrients such as nitrogen, phosphorus, potassium, calcium, magnesium and boron (Bin, 1983; Jacks et al., 1955; Stephenson and Schuster, 1945). Mulches may serve an important role in nutrient cycling.

${ }^{1}$ Farm advisor, University of California Cooperative Extension, 669 County Square Drive, Suite 100, Ventura CA, 93003; corresponding author.

${ }^{2}$ Farm advisor, University of California Cooperative Extension, 669 County Square Drive, Suite 100, Ventura CA, 93003.

${ }^{3}$ Professor, Department of Plant Pathology, University of California, Riverside, CA 92521. 


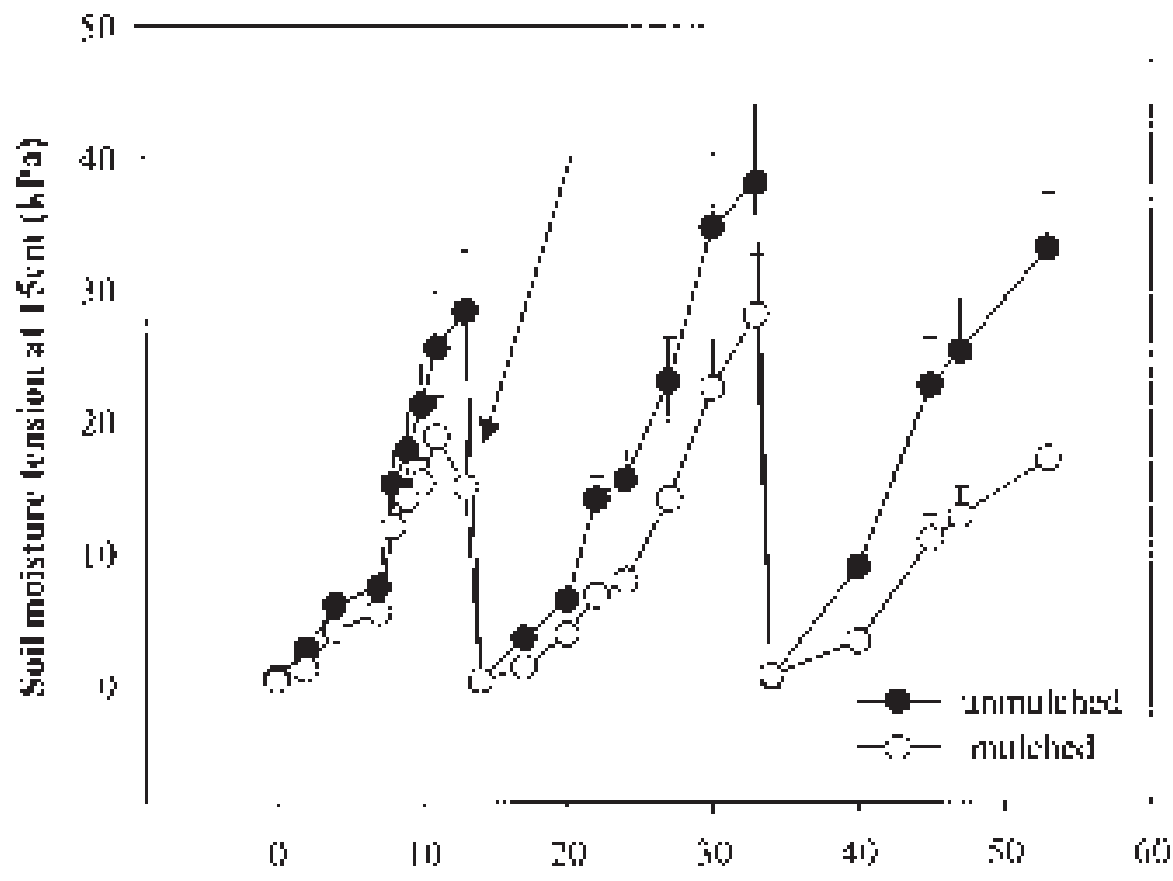

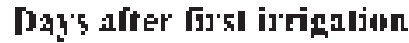

Fig. 1. Soil moisture tension under mulched and unmulched trees (from Downer, 1998). Each point represents the mean of 16 replications; bars are the $\mathrm{SE}, 15 \mathrm{~cm}=5.9$ inches, $1 \mathrm{kPa}=20.9 \mathrm{lb} / \mathrm{ft}^{2}$.

Mulches simulate litterfall in forests; a process necessary to nutrient cycling of minerals from deposited organic materials back into the trees that produced the litter. Over time, significant mineral nutrient increases are made to mulched soil and these are directly related to mulch thickness at application. Certainly in tropical agriculture, nutrient management is an important aspect of disease control because nutrient depleted plants are more susceptible to many diseases (Agrios, 1997); however, in the Mediterranean climate of California, nutrients are rarely limiting and in steady supply from organic or inorganic fertilizers. Although mulches add nutrients to soil as they mineralize, we do not feel that this plays a significant role in the limitation of root disease in California groves since nutrients are not limiting. However, for growers in the transition from conventional cropping systems to organic methods, mulching provides an organic source of plant minerals consistent with the guidelines of certified organic production methods, prevents nutrient deficiencies and conditions that might otherwise favor disease development. absorption of heat during the day and radiation of heat at night, they can increase the danger of frost and so predispose young or tender plants to diseases that follow frost or freeze injury.

Missapplication of mulches (mounding around the stem) can also result in injury or disease of mulched trees and shrubs. We have seen canker fungi infect trees when mulch covered the stem of a woody plant at its crown (where stem and roots are joined).

\section{Amelioration of disease- predisposing factors}

Mulches can reduce some of the environmental conditions that predispose plants to root disease. Conditions affecting the susceptibility of plants should be carefully considered when attempting to limit Phytophthora diseases (Duniway 1983). Mulches reduce fluctuations in soil temperature, sometimes resulting in reduced plant stress and improved root growth especially where summer temperatures are high. Since soils dry more slowly under mulches, soil salinity does not increase or spike as sharply as drying unmulched soils. Salinity is a major predisposing factor to disease from Phytophthora. (McDonald, 1982, 1984; MacDonald et al., 1984). Increasing soil salinity makes roots more susceptible to attack from Phytophthora by inhibiting root defense systems. The avoidance of large swings in soil salinity as soils dry and are rewetted helps roots to resist infection, especially in avocado a tree that is very surface rooted.

When organic mulches decompose, the soluble carbon moves down into soil layers forming polysaccharides that bind clay particles into microaggregates (Tisdall and Oades, 1982). Over several years, this organic aggregation can increase drainage characteristics of heavy soils, decreasing saturation times and increasing infil-

Table 1. Growth and root length of avocado from mulched and unmulched soils. All within treatment comparisons of mulch and no mulch effects are significant for each rootstock according to significant $(P<0.05)$ analysis of variance and mean separations by Waller's $K$ ratio $t$ test. $1.00 \mathrm{~m}^{3}=35.31 \mathrm{ft}^{3}$ and $1.0 \mathrm{~cm}=0.39$ inch. Table adapted from Downer et al., $2001 \mathrm{c}$.

\begin{tabular}{lccccc}
\hline & \multicolumn{2}{c}{ No mulch } & & \multicolumn{2}{c}{ Mulched } \\
\cline { 2 - 3 } Rootstock & $\begin{array}{c}\text { Canopy } \\
\left.\text { vol } \mathbf{( m}^{\mathbf{3}}\right)\end{array}$ & $\begin{array}{c}\text { Root length } \\
(\mathbf{c m})\end{array}$ & & $\begin{array}{c}\text { Canopy } \\
\left.\mathbf{v o l} \mathbf{( m}^{\mathbf{3}}\right)\end{array}$ & $\begin{array}{c}\text { Root length } \\
(\mathbf{c m})\end{array}$ \\
\hline Duke 7 & 1.56 & 13.3 & & 3.39 & 19.0 \\
Thomas & 3.96 & 5.1 & & 4.91 & 14.5 \\
\hline
\end{tabular}




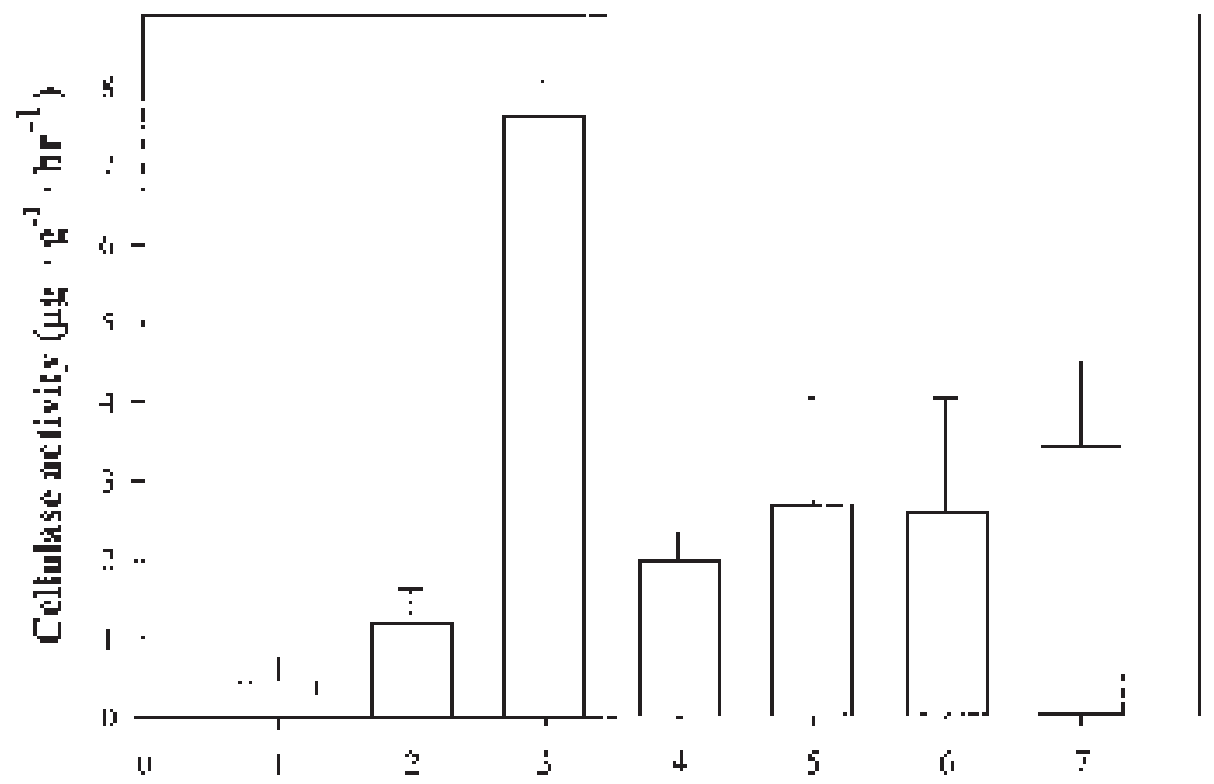

Fig. 2. Cellulase activity of mulches inoculated with various wood decay fungi. Enzyme activities are micrograms glucose released from carboxymethylcellulose substrate per gram of sample per hour (from Downer, 1998). Treatments: 1 = soil, no mulch; 2 = mulch, no fungi; 3 = Ceraceomyces tessulatus; 4 = Chactomium globosum; 5 = Agrocybe molesta; 6 = Cyathus olle; 7 $=$ Phanerochaete chrysorbiza. Bars indicate $\mathrm{LSD}_{0.05}$.

tration rates (Martens and Frankenberger, 1990). Continual mulching with organic substrates improves soil permeability, soil drainage, and aggregate development (Merwin et al., 1994). Thus, the long-term outlook for control of root diseases caused by Oomycete fungi in mulched soils is still quite good. In our work with avocado, we observed this in a tensiometer study of mulched and unmulched trees (Fig. 1). The arrow in Fig. 1 indicates a data point where the mulched soil matric potential has sharply fallen while the tensiometer values of unmulched trees continues to rise. This reading was taken $30 \mathrm{~min}$ after the start of an irrigation and clearly indicates tensiometer response under mulches is much faster, thus revealing greater infiltration rates in mulched trees. We also observed considerable runoff of microsprinkler irrigated unmulched trees while mulched trees had little or no runoff.

\section{Microbiological effects of mulches (biological control)}

Microbial antagonism, hyperparasitism, and phenomena that exploit one or several organisms against root pathogens are viable alternatives to chemical control and are being researched vigorously around the world (Erwin and Ribeiro, 1996). For growers transitioning to organic methods there are few if any fungicidal tools; thus biological control is looked upon as a viable control method for limiting disease. Mulched soils nearly always support larger and more diverse populations of microorganisms than do unmulched soils (Broadbent and Baker 1974; Downer et al., 2001a). Such organisms (bacteria, fungi and actinomycetes) are thought to inhibit fungal pathogens via competition, parasitism and antibiosis.

The Ashburner system of biological control is well known and frequently cited (Cook and Baker, 1983) as a method for reduction of Phytophthora cinnamomi in avocado groves. The origins of the system came from observations that the root rot pathogen $P$. cinnamomi could not be recovered in rainforest soils even though these were down slope from infested cleared lands. This inspired the grower Guy Ashburner to attempt to recreate rainforest conditions in his grove by increasing organic matter content through mulching and by the addition of lime and manures. Since cleared jungle soils are soon depleted of base cations especially calcium and since $\mathrm{pH}$ usually falls, lime was a necessary component. The Ashburner method utilizes copious additions of organic mulches as well as a calcium source such as lime or gypsum to suppress root rot disease. The method was experimentally investigated by Broadbent and Baker (1974) and thoroughly reviewed by Cook and Baker (1983) in their classic text on biological control. Baker (1978), theorized that rain forest ecology may suppress Phytophthora because high organic matter, calcium, and nitrogen levels stimulate antagonist microorganisms; the soil $\mathrm{pH}$ becomes favorable for bacteria, high organic matter and calcium levels increase soil structure and drainage; high calcium levels increase host resistance; and healthy plants remove water from the soil thus decreasing waterlogging. Association of bacteria with dying hyphae of Phytophthora in the Ashburner system promised hope for disease control and has provided a quest for plant pathologists to find new biological control organisms with the qualities necessary to institute control in soils that are conducive to disease. However, most microbial antagonists that were selected and tried in subsequent field studies produced very limited results (Malajczuk, 1983). Despite all the theory and research, no single mechanism or organism has ever been conclusively associated with biological control of P. cinnamomi in the field.

Downer (1998) adapted the Ashburner method for California avocado growers. Recycled yard trimmings are the primary organic matter source. Calcium is supplied by gypsum instead of limestone and we have omitted manures since most growers use inorganic fertilizers. For transitional farmers manures could be substituted for conventional inorganic fertilizers. The method has shown some success in controlling the disease in replanted orchards. Mulches may be used to promote growth and yield of avocado in Phytophthora infested soils but care must be taken not to over-irrigate since mulches tend to increase soil moisture. Since Phytophthora rapidly reproduces in saturated soil, any disease amelioration from mulching can be lost if soil moisture remains saturated during long periods of time.

The Ashburner system is a frequently cited example of how biological control of a soilborne fungus can be 


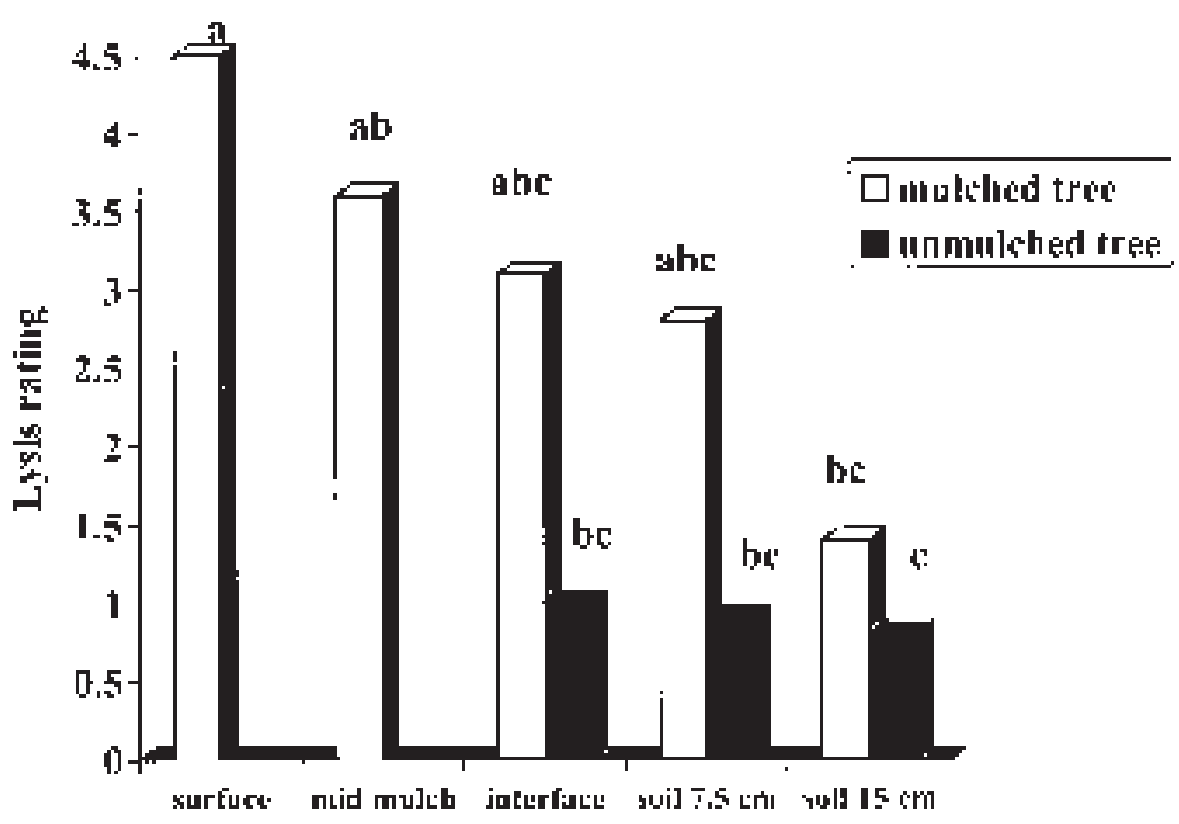

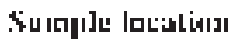

Fig 3. Lysis of Phytophthora in mulched and unmulched soils at various soil depths (from Downer, 1998). Bars with the same letter are not significantly different according to $\mathrm{LSD}_{0.05} ; 7.5 \mathrm{~cm}=2.95$ inches, $15 \mathrm{~cm}=5.9$ inches.

successful. Still, there has been little progress understanding the underlying mechanisms of control in this system. Yard trimmings mulches appear to stimulate abundant, healthy root development in the vicinity of the mulches and increase growth of avocado (Table 1). We found that mulches increased microbial activity and cellulase enzyme activities relative to unmulched control trees (Downer et al., 2001a). Mulch enzyme activities correlated well to increased populations of saprophytic fungi growing in mulches. In our studies of wood chip mulches, we found that wood decay fungi predominated there and these fungi produced exogenous cellulase enzymes (Fig. 2). These enzymes are known to lyse cell walls and prevent sporulation by Phytophthora, because the cell walls of Phytophthora are composed of cellulose and related glucans. We have seen increased lysis of Phytophthora in mulches compared to unmulched soils (Fig. 3) We also have shown that cellulase and other glucanases are destructive to the various life history stages of Phytophthora cinnamomi (Downer et al., 2001b). We believe these enzymes are the inhibitory factors toward Phytophthora that have been reported in mulch, many suppressive soils, and in the Ashburner system. The presence of cellulytic enzymes in mulches protects roots growing there from attack by Phytophthora. This protection is not afforded roots produced in deeper soil layers, because the enzymes are absorbed and deactivated on clay particles (Harter and Stolzy, 1971). Thus, although the mulching system controls the disease, control is limited to organic layers in soils.

Long term effects of continuous mulching (more than 5 years) have not been well studied or reported in the literature. Additional studies are also needed on the effects of amending heavy textured, Phytophthora infested, soils prior to planting. For growers that want to transition from conventional farming systems to an organic approach for avocado production, it is possible to limit disease due to Phytophthora cinnamomi, supply adequate nutrition and save water with the application of coarse organic yardwastes mulches. Mulches should have a high carbon to nitrogen ratio to favor colonization by wood decay fungi. During this transition, growers should be cautious in their management of water as mulching (early after application) can exacerbate excess soil moisture and promote disease. Over longer periods (after at least 2 years) mulching in concert with careful irrigations should help control root disease in avocado groves.

\section{Literature cited}

Agrios, G.N. 1997. Plant pathology. $4^{\text {th }}$ ed. Academic Press, San Diego, Calif.

Baker, K.F. 1978. Biological control of Phytophthora cinnamomi. Intl. Plant Prop. Soc. Comb. Proc. 28:72-79.

Bin, J. 1983. Utilization of green manure for raising soil fertility in China. Soil Sci. 135:65-69.

Broadbent, P. and K.F. Baker. 1974. Behavior of Phytophthora cinnamomi in soils suppressive and conducive to root rot. Austral. J. Agr. Res. 25:121-137.

Cook, R.J. and K.F. Baker. 1983. The nature and practice of biological control of plant pathogens. Amer. Phytopathol. Soc. Press, St. Paul, Minn.

Downer, A.J. 1998. Control of avocado root rot and Phytophthora cinnamomi Rands in mulched soils. PhD diss., Univ. Calif., Riverside.

Downer. J. and D. Hodel. 2000. The effect of mulching and turfgrass on growth and establishment of Syagrus romanzoffiana (Cham.) Becc., Washingtonia robusta $\mathrm{H}$.Wendl. and Archontophoenix cunninhamiana (H. Wendl.) H. Wendl. \& Drude in the landscape. Sci. Hort. 87:85-92.

Downer, A.J., J.A. Menge, and E. Pond. 2001a. Association of cellulytic enzyme activities in eucalyptus mulches with biological control of Phytophthora cinnamomi Rands. Phytopathology 91:847-855.

Downer, A.J., J.A. Menge, and E. Pond. 2001 b. Effects of cellulytic enzymes on Phytophthora cinnamomi Rands. Phytopathology 91: 839-846.

Downer, J., J.A. Menge, H.D. Ohr, B.A. Faber, B.S. Mckee, E.C. Pond, M.G. Crowley, and S.D. Campbell. 2001c. The effect of yard trimmings as a mulch on growth of avocado and avocado root rot caused by Phytophthora cinnamomi. Yearbook Calif. Avocado Soc. 83:87-104.

Duniway, J.M. 1983. Role of physical factors in the development of Phytophthora diseases, p. 175-187 In: D.C. Erwin, S. Bartnicki-Garcia, and P.H. Tsao (eds.). Phytophthora: Its biology, taxonomy, ecology, and pathology. Amer. Phytopathol. Soc., St. Paul, Minn.

Erwin, D.C. and O.K. Ribeiro. 1996. Phytophthora diseases worldwide. Amer. Phytopathol. Soc. Press, St. Paul, Minn.

Faber, B., A.J. Downer, and J.A. Menge. 2001. Differential effects of mulch on citrus and avocado. Acta Hort. 557:303307.

Harter, R.D. and G. Stolzy. 1971. Forma- 
tion of clay protein complexes. Soi. Sci. Soc. Amer. Proc. 35:383-389.

Jacks, G.V., W.D. Brind, and R. Smith. 1955. Mulching. Commonwealth Bur. Soil Sci. Tech. Comm. 49.

MacDonald, J.D. 1982. Effect of salinity stress on the development of Phytophthora root rot on chrysanthemum. Phytopathology 72:214-219.

MacDonald, J.D. 1984. Salinity effects on the susceptibility of chrysanthemum root to Phytophthora cryptogea. Phytopathology 74:621624.

MacDonald, J.D., T.J. Swiecki, N.S. Blaker, and J.D. Shapiro. 1984. Effects of salinity stress on the development of Phytophthora root rots. Calif. Agr. 38:23-24.

Malajczuk, N. 1983. Microbial antagonism to Phytophthora, p. 197-218. In: D.C. Erwin, S. Bartnicki-Garcia, and P.H. Tsao (eds.).
Phytophthora: Its biology, taxonomy, ecology and pathology. Amer. Phytopathol. Soc. Press, St. Paul, Minn.

Martens, D.A. and W.T. Frankenberger. 1990. Modification of infiltration rates in an organic amended irrigated soil. Agron. J. 84:707-717.

Merwin, I.A.., W.C. Stiles, and H.M. van Es. 1994. Orchard groundcover management impacts on soil physical properties. J. Amer. Soc. Hort. Sci. 119:216-222.

Robinson, D.W. 1988. Mulches and herbicides in ornamental plantings. HortScience 23:547-552.

Stephenson, R.E. and C.E. Schuster. 1945. Effect of mulches on soil properties. Soil Sci. 59:219230 .

Tisdall, S.J. and J.M. Oades. 1982. Organic matter and water-stable aggregates in soils. J. Soil Sci. 33:141-163. 